\title{
Analytical and Conceptual Perspectives toward Behavioral Elements of Collaborative Delivery Models in Construction Projects
}

\author{
Sina Moradi * , Kalle Kähkönen and Piia Sormunen
}

check for

updates

Citation: Moradi, S.; Kähkönen, K.;

Sormunen, P. Analytical and

Conceptual Perspectives toward

Behavioral Elements of Collaborative

Delivery Models in Construction

Projects. Buildings 2022, 12, 316.

https://doi.org/10.3390/buildings

12030316

Academic Editors:

Jurgita Antucheviciene and

Paulo Santos

Received: 25 January 2022

Accepted: 5 March 2022

Published: 7 March 2022

Publisher's Note: MDPI stays neutral with regard to jurisdictional claims in published maps and institutional affiliations.

Copyright: () 2022 by the authors. Licensee MDPI, Basel, Switzerland. This article is an open access article distributed under the terms and conditions of the Creative Commons Attribution (CC BY) license (https:/ / creativecommons.org/licenses/by/ $4.0 /)$.
Faculty of Built Environment, Tampere University, 33720 Tampere, Finland; kalle.kahkonen@tuni.fi (K.K.); piia.sormunen@tuni.fi (P.S.)

* Correspondence: sina.moradi@tuni.fi

\begin{abstract}
Collaborative models and working practices have considerably contributed to the evolution of construction project delivery in the last four decades. The promising performance results of construction projects with collaborative delivery models are mostly attributed to their behavioral elements (e.g., mutual trust), which have been frequently mentioned in the literature. However, the interrelationships between these behavioral elements as well as the enablers of these behavioral elements are two knowledge gaps which need to be addressed. Therefore, this study aims to fill the mentioned knowledge gaps by addressing the behavioral elements of collaborative project delivery models from analytical and conceptual perspectives. To do so, a systematic literature review was undertaken by locating 201 relevant studies and reviewing them. This was followed by the thematic analysis of the obtained research data and the development of a model for meeting this study's objectives. The findings present a model, illustrating the behavioral elements of collaborative delivery models in construction projects, their interrelationships, as well as their enablers. The model reveals that the establishment of equality and mutual respect between project team members is a fundamental step toward mutual trust and open communication. These findings can be insightful for the research community and project professionals interested in collaborative construction project delivery.
\end{abstract}

Keywords: collaborative project delivery models; collaborative construction; lean project delivery; integrated project delivery; alliance; partnering

\section{Introduction}

The successful performance of construction projects is considerably dependent on the delivery model that is employed for undertaking the project [1]. Construction project delivery models have been a means of accomplishing project definition, design, planning, and execution phases by delineating the contractual relationships and allocating the risks and rewards of the project to the key parties (e.g., [2-5]). This perspective can be helpful in understanding the terminology associated with the traditional construction project delivery models (e.g., design-bid-build; design-build, engineering-procurement-construction) which represent an emphasis on the division. This means that dividing the construction project phases between the key parties based on their contractual responsibilities usually results in their separation and working in their own silos throughout the project [6].

For instance, the contractor in traditional construction project delivery models is usually not involved in the project definition, planning, and design, or at least, this involvement is not early enough. The explained division consequently causes a few disadvantages associated with the traditional delivery models of construction projects. Some of these disadvantages are the late involvement of key project participants, the lack of integration, several design errors and reworks, litigation and claims, cost, and time overrun as well as mistrust and adversarial relationships [7-10]. It can be argued that the mentioned challenges have been the main drivers of the changes and developments that have happened in construction project delivery in the last four decades (Forbes and Ahmed, 2010). 
The mentioned changes and developments, in the holistic view, account for traditional delivery models turning into collaborative ones (e.g., partnering, alliancing, integrated project delivery). The key features of collaborative delivery models include the early involvement of key parties, shared risk-reward, joint project planning and control, jointly developed and validated goals, and trust-based relationships for collaboration and cooperation (e.g., [11,12]). Accordingly, collaborative delivery models are usually characterized by limited change orders, reduced liability exposure, fixed profit, and profit based on project outcome, unlike traditional delivery models (e.g., [13]). In construction projects with collaborative delivery models, project participants work together (collaboration) and exchange information (cooperation) with aligned interests and mutual trust for the best of the project (e.g., [14-16]).

In addition to the pure forms of traditional and collaborative deliveries, there has been also a trend in the construction industry whereby traditional delivery models are combined with collaborative practices (e.g., co-located teams). It can be said that this form of construction project delivery implies being collaborative in traditional contracts. In the literature, construction projects with collaborative delivery models (e.g., integrated project delivery, alliance, partnering) and/or traditional ones (e.g., design-bid-build), comprising collaborative practices (e.g., co-located teams), are also called collaborative construction projects (e.g., [17]).

Construction projects with collaborative delivery models have had promising performance results compared to traditional ones, particularly in terms of time, cost, and quality [18-25]. This has led to a growing trend of using collaborative delivery models and working practices in construction projects in many countries (for instance in the USA, UK, Australia, Finland, and Norway) [26]. In Finland, almost 100 construction projects with collaborative delivery models have been launched since 2011 with a total value of EUR 5.5-6 billion [15]. This trend of collaborative delivery models in the industry has in turn caused substantial interest in the research community with regard to the scholarly activities addressing the different aspects of collaborative project delivery (e.g., [27-45]).

The promising performance results of construction projects with collaborative delivery models are mainly attributed to their different elements and characteristics compared to those of traditional ones (e.g., $[13,17])$. These elements, which are mostly behavioral (e.g., mutual trust, open communication), have been frequently mentioned in the literature (e.g., [46-48]). However, the interrelationships between these behavioral elements of collaborative delivery models as well as the enablers of those behavioral elements are two knowledge gaps which need to be addressed. This study aims to look at these behavioral elements from analytical and conceptual perspectives. Such perspectives, when utilized together, will enable performing a thorough review and identification of the behavioral elements, followed by exploring their enablers and the linkages between them. According to the mentioned gap and purposes, this study aims to answer the following questions:

RQ1. What are the behavioral elements in the collaborative delivery models of construction projects?

RQ2. How are the interrelationships between the behavioral elements of the collaborative delivery models of construction projects?

RQ3. What are the enablers for the behavioral elements of the collaborative delivery models of construction projects?

The resulting article is structured in four sections. The next section presents the theoretical background. Then, the methodology is explained, which is followed by presenting and discussing the findings. Finally, the conclusions, drawn from the findings, are stated. 


\section{Theoretical Background}

\subsection{Definition}

"Collaborative delivery model" is one of the umbrella terms which has been utilized by different scholars in reference to alliance, partnering, integrated project delivery, and lean project delivery (e.g., [49]). According to [50,51], alliance, partnering, integrated project delivery, and lean project delivery are the existing pure collaborative delivery models which share some common features, including the early involvement of key parties, transparent financials, shared risk and reward, joint decision making, and a collaborative multiparty agreement. There is also a new form of collaborative delivery in which traditional delivery models (e.g., design-build) are combined with collaborative practices (e.g., co-located and integrated teams) for benefiting from the advantages of both traditional (competitive price, insurance) and collaborative delivery models (e.g., integrated project organization, fair share of risk-reward, the early involvement of key project participants). A recent study [15] has defined collaborative delivery models as the joint design, planning, control, and management of construction projects by its participants based on their early involvement in the project, trust-based relationships, open communication, and fair share of risk-reward. This source has also provided clarification in terms of the differences between collaborative and traditional delivery models which is in line with the one presented by [52]. Table 1 shows the common features of collaborative delivery models and their differences with traditional delivery models.

Table 1. Collaborative delivery models: common features and differences with traditional delivery models.

\begin{tabular}{|c|c|}
\hline \multicolumn{2}{|c|}{ Collaborative Delivery Models } \\
\hline Common Features & Differences with Traditional Delivery Models \\
\hline Early involvement of key participants & Focus is on the production system, not the contract \\
\hline Joint planning, design, and control & Design and planning priorities joint design of the product and process and \\
\hline Joint decision making & pays attention to the completion of the tasks where they are ready, not as soon \\
\hline Open book approach for cost management & as possible; contingency reserves are used for reducing system variability, not \\
\hline Fair share of risk and reward & for self-interest \\
\hline Trust-based relationship & Decision making is unanimous, not divided \\
\hline Open communication & Learning constantly happens throughout the project life cycle, not occasionally \\
\hline Multi-party agreement & Stakeholder interests are aligned, not divided \\
\hline \multicolumn{2}{|c|}{ References: $[13,15,52]$} \\
\hline
\end{tabular}

\subsection{Behavioral Elements of Collaborative Delivery Models}

Collaborative delivery models, as the earlier explanations imply, have a significant difference compared to traditional ones. This difference refers to the change of people's mindset (the established set of attitudes held by someone) and consequently their behavior from working in silo and having adversarial relationships with other project participants toward collaboration (working together) and cooperation (exchanging information) based on mutual trust and aligned commercial interests solely for the common good, which is the project success. Thus, the behavioral elements of collaborative delivery models can be defined as various aspects and forms of human resources' constructive and continuous interactions for accomplishing something, which cannot be achieved by working in silos with mistrust and out of self-interest.

\subsection{Existing Research-Based Knowledge concerning Collaborative Delivery Models \\ 2.3.1. Alliance}

The research community has been actively studying the different aspects of alliance construction projects since 2000. Providing a clear definition of alliance construction projects has been one of the main efforts in the previous studies (for instance, [53-57]). Lloyd and Varey [58] stated that the alliance is a fully integrated and congenial environment which provides the possibility for the successful merging of two different organizational cultures. According to [59], alliancing has certain defining elements, which include open book cost 
management, integrated project team, pain/gain-share, the aligned commercial objectives of the client and project participants, no-disputes clause, unanimous decision making, incentivized cost reimbursement.

Alliance team integration is another topic which has been addressed by different scholars. Ibrahim et al. $[60,61]$ identified the key indicators of alliance team integration, which include team leadership, trust and respect, single team focus on project objectives and key results areas, collective understanding, commitment from project alliance board, the creation of single and collocated alliance team, and free flow communication. They also stated that influencing the leadership for achieving successful integration practice requires a team-centric approach which contains four elements of task and relationship-oriented behaviors; collaborative learning environments; cultivating cross-boundary networks; and collaborative governance. Moreover, a study conducted by [53] found that everyday dynamics are very important for managing integration. They also stated that project complexity and a lack of previous collaboration experience among participants increase the uncertainty of the project and create a need for high levels of integration.

An incentive structure, relationship building and management, and success factors for alliance projects are other major topics which have been studied in the context of alliance construction projects. Regarding the incentive structure, Hauck et al. [7] stated that a constructive incentive system aligns individual interests with the goals of the project team. In addition, it has been mentioned that a fair system of risk-reward sharing between project parties is a driving factor for collaborative behavior, achieving cost efficiencies, and producing innovative design solutions [62]. In this regard, Laan et al. [63] and Hietajärvi et al. [64] identified that an alliance incentive structure reduces opportunistic behavior serving self-interest but creates a willingness for proactive opportunity-seeking when it is combined with idea-generating processes.

Concerning relationship building and management in alliance projects, a study undertaken by [6] identified that trust, adequate resources, open communication, coordination, integration, top management support, creativity, and goal alignment are critical factors for the successful formation, operation and evaluation phases of the relationship. Similarly, Lloyd and Varey [58] emphasized the significance of free-flowing, integrated and bi-directional communication for having good client-contractor relationships in the alliance projects. Moreover, it has been mentioned that having cooperative relationships in the alliance projects requires considerable efforts into the inclinations for opportunistic behavior. Furthermore, a recent study carried out by Aaltonen et al. [65] found that both informal and formal socialization mechanisms are important for creating relational capital. They found that informal socialization mechanisms are useful in both building relational capital (in terms of developing personal relationships, trust, and integration) in the tendering phase and enhancing it in the development phase, whereas formal socialization mechanisms (e.g., co-locational space) are mainly effective in the development phase for maintaining relational capital.

Success factors for alliance construction projects is another major topic which has been addressed in the literature, as mentioned earlier. Young et al. [59] identified 22 success factors such as strong commitment by client and senior management, mutual goals and objectives, dispute resolution process, flexibility and adaptability, open communication, and trust. Moreover, Hietajärvi et al. [66] stated that four groups of contractual, behavioral, relational, and operational skills are critical for the successful initiation and implementation of alliance projects.

In addition to the explained topics, communication, culture, collaboration and cooperation, cost management, control mechanisms, and risk management have also been studied in the context of alliance construction projects [55,67-72].

\subsubsection{Integrated Project Delivery (IPD)}

Akin to alliance, integrated project delivery has also been an interesting and focused research topic. Collaboration and integration constitute the area in which most research 
studies in the context of integrated project delivery have been undertaken. According to Kent and Becerik-Gerber [73], collaboration is influenced by relationships between project stakeholders rather than contracts. A study conducted by Lee et al. [74] found that collaboration contributes toward team integration. Moreover, it has been stated that the frequent interaction of project parties in IPD projects foster mutual trust and improve team collaboration [75,76]. Another study carried out by Mollaoglu-Korkmaz et al. [77] revealed that factors such as the early involvement of the contractor in the project can be useful for team integration. Additionally, a few studies have stated that IPD's collaborative features considerably contribute toward project success [78-80]. According to Rowlinson [81], collaboration and cooperation in projects require a building information model that all can access, comprehend, and handle.

Project performance, incentive system, risk and insurance, and success factors are other major topics which have been studied by different scholars in the context of integrated project delivery. In terms of performance, a few studies have reported that IPD projects outperform traditional construction projects in terms of time, cost, quality, communication, and number of change orders $[18,19,22-24,82]$. Concerning the incentive system, it has been mentioned that financial and nonfinancial motivations are both important to IPD projects and both of them are needed in a constructive incentive system [83-85].

Risk allocation and insurance were mentioned in some of the previous studies as a big concern of IPD projects [73,85]. One reason for this problem, according to El-Adaway et al. [86], is that multiparty agreements are not covered by insurance policies or products. In other words, the contracting team is not supported against third-party claims. Consequently, there is still a fundamental lack of connection between the contractual arrangement and the insurance program that is expected to protect the project and its participants' interests. Thus, relational contract agreements are different in terms of treating insurance and risk issues.

Success factors for IPD projects is the last (but not least) major topic which has been interesting for the research community. Factors such as the symmetrical alignment of shared responsibilities, early involvement of key project participants, financial incentives, collaboration and cooperation, and trust have been frequently mentioned by different scholars $[73,85,87,88]$.

\subsubsection{Lean Project Delivery}

In the area of lean construction, two major topics can be recognized in the literature which include efforts to define lean construction/project delivery and the combination of lean with other collaborative delivery models and/or working practices (e.g., [89-91]). Regarding the former one, Enache-Pommer et al. [92] defined lean as the elimination of waste in design and operational processes. According to Daniel and Pasquire [93], lean production philosophy supports the realization of social value purposes in construction project delivery through helping construction organizations to conceptualize the communities and physical environment where they operate as their customers, rather than mere people and place. Moreover, a recent study conducted by Mesa et al. [51] explained the characteristics of a lean operational system (flow-based approach, predictable and rapid workflow, project optimization, and lean tools), lean behaviors (collaboration, trust, promise based management and continuous improvement) and lean principles (defining customer-oriented value, mapping the value stream, creating flow, pull planning, managing continuous improvement).

As mentioned earlier, the combination of lean with other collaborative delivery models and/or working practices has been addressed by different scholars. For instance, EnachePommer et al. [92] conducted a study concerning integration of the lean, green, and building information modeling (BIM) and found that integrating greening strategies, lean principles, and BIM for the delivery of healthcare facilities results in building an optimum healthcare facility. Another research study carried out by Nguyen and Akhavian [94] found that there are six crucial characteristics (e.g., durable value and continuous development, customer 
satisfaction and waste elimination, communication and achievement metrics) required for an effective coordination between integrated project delivery (IPD), lean construction, and BIM. In addition, Ahuja [95] stated that the combination of lean and green philosophies contributes to achieving sustainability in terms of economic, social, and environmental values. Another study conducted by Mesa et al. [51] addressed IPD and lean project delivery (LPD) as two different delivery models and concluded that the core of IPD and LPD is to facilitate the utilization of integrated project organizations, relational contracting, and integrated process as mechanisms to integrate a project delivery system. This source also clarified that the main difference between LPD and IPD delivery systems originates from the operational system. The IPD system addresses no specific operational system, whereas the LPD system utilizes an operational system based on lean principles and the use of lean tools such as target value design, last planner system, and set-based design.

In addition to the explained topics, several other studies have also been undertaken concerning barriers for adopting lean project delivery [96,97], contractual issues [98,99], cost management [100], green projects [92,101], lean processes [102], last planner system and location-based management system [103], social value [93], and success factors [104].

\subsubsection{Partnering}

Analyzing the literature on partnering construction projects shows that, among several addressed topics, partnering definition, partnering performance, and partnering success factors have gained considerable attention from the research community.

Partnering has been defined and explained by several scholars (for instance, [105-114]). For instance, it was defined by Brown [115] as a realignment which involves choosing to act vs. react and planning vs. abdicating responsibility and acknowledging that there is greater benefit to resolving the problem than placing the blame. Gransberg et al. [116] defined partnering as a change in business behavior and not a technical change to a contract, and pointed out that high-level trust among the key project participants is required to achieve the positive influence of partnering. Additionally, Conley and Gregory [117] stated that the partnering agreement is not legally binding because it serves as a reminder for commitment to a successful project. Another definition of partnering has been provided by El-Adaway $[118,119]$, which clarifies the required elements of a partnering contract, including duties of fairness, teamwork, mutual cooperation and shared financial motivation, as well as clearly defined roles and duties in a fully integrated document. In a recent study, Hosseini et al. [26] defined partnering as a collaborative procurement form, focusing on the integration of the project design and delivery by weighting collaboration and coordination between involved parties. This study also identified 30 elements of partnering including the early involvement of contractors, target price with bonus or malus, the inclusion of consultants in the partnering group, and the co-location of the partnering group.

In terms of partnering performance, it has been frequently mentioned in the literature that partnering projects are considerably successful in terms of controlling cost and time growth, quality, and working relationships [117,120-125]. Moreover, it has been stated that partnering enhances the risk of management, and contributes to mutual trust, collaboration, cooperation, and team integration [126,127].

Regarding partnering success factors, more than 10 studies have been carried out to address the subject of interest. For instance, a study undertaken by $\mathrm{Zhang}$ and $\mathrm{Ku}$ maraswamy [128] identified seven success factors for partnering projects including a wellestablished legal system, business-friendly environment, fair and transparent project development system, and clear administration. Another study performed by Chan et al. [129] stated that the establishment and communication of a conflict resolution strategy, willingness to share resources among project participants, a clear definition of responsibilities, commitment to a win-win attitude and the regular monitoring of the partnering process are critical factors for partnering success. Moreover, a few studies have mentioned that factors such as open communication, mutual trust, equity, and the early identification and engagement of all potential stakeholders are critical for partnering success [130-134]. 
In addition to the explained research efforts, several other studies have also been carried out and addressed topics such as an application of partnering [135,136]; building information modelling [137], barriers to successful partnering [134], conflict management [138], owner-contractor relationships [139-141], partnering implementation [142,143], and trust $[144,145]$.

\section{Methodology}

\subsection{Research Design}

This study employed a systematic literature review for meetings its objectives. Locating the relevant studies from four databases was followed by excluding irrelevant ones and repetitions through abstract review. Finally, the full texts of the relevant studies were reviewed, and the obtained research data were analyzed through thematic analysis method [146]. The whole process of data collection and analysis in this research is illustrated in Figure 1 and explained in detail in the following sub-sections.

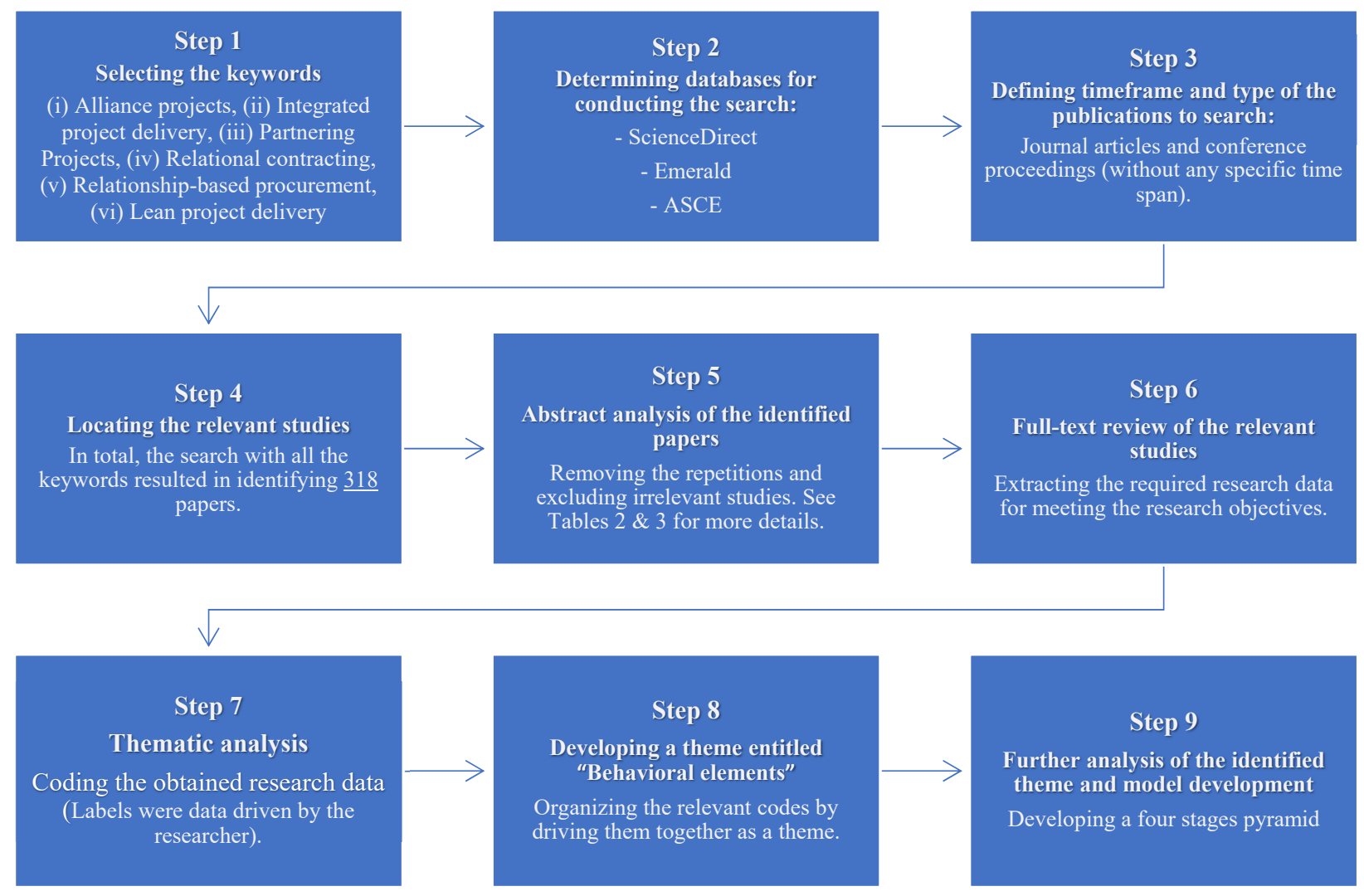

Figure 1. The research process including data collection and analysis.

\subsection{Keyword Selection and the Search for Locating the Relevant Studies}

The search for finding relevant studies was performed in January 2021 using six keywords: (i) alliance projects; (ii) lean project delivery; (iii) partnering projects; (iv) integrated project delivery; (v) relational contracting; and (vi) relationship-based procurement. The keywords were selected based on state-of-the-art studies on collaborative delivery models (e.g., $[12,49,50])$. Then, the ScienceDirect, Emerald, and American Society of Civil Engineers (ASCE) databases were utilized for locating the relevant studies. Since very few studies have been found in the mentioned databases for two of the keywords (relationship-based procurement and lean project delivery), the Google Scholar database was also utilized to search for the relevant studies with those two keywords on their title. In the end, 318 papers were located as a result of searching for the presence of the mentioned six keywords on the title of the publications in four databases. Then, the abstract of all the studies were 
reviewed to ensure that the identified studies matched the collaborative delivery models of the construction projects. As a result of this effort, 117 studies were excluded, and the remaining 201 relevant studies were analyzed through thematic analysis.

\subsection{Descriptive Statistics of the Conducted Search for Locating Relevant Studies}

The following Tables 2 and 3 show the publication type of the analyzed studies and detailed descriptive statistics concerning the conducted search for locating the relevant studies. No specific time span was applied in locating the relevant studies to ensure the comprehensiveness of the search. However, as can be seen in Figure 2, the publication period of $61 \%$ of the 201 analyzed studies was between 2011 and 2020. This can be of importance as the relevance of recent publications is usually higher.

Table 2. Publication type of the analyzed studies.

\begin{tabular}{cccccccc}
\hline \multirow{2}{*}{ Type of Publication } & \multicolumn{9}{c}{ Database } & \multicolumn{2}{c}{ Total } \\
\cline { 2 - 7 } & ASCE & Emerald & $\begin{array}{c}\text { Google } \\
\text { Scholar }\end{array}$ & ScienceDirect & & \\
\hline Journal articles & 72 & 40 & 19 & 30 & 161 & $80 \%$ \\
\hline Conference proceedings & 15 & 0 & 13 & 12 & 40 & $20 \%$ \\
\hline & \multicolumn{2}{c}{ Total } & & & 201 & $100 \%$ \\
\hline
\end{tabular}

Table 3. Descriptive statistics of the search for relevant studies in the literature.

\begin{tabular}{|c|c|c|c|c|c|}
\hline Utilized Keyword & Database & $\begin{array}{c}\text { Number of } \\
\text { Located Studies }\end{array}$ & $\begin{array}{c}\text { Number of } \\
\text { Excluded } \\
\text { Studies }\end{array}$ & Criteria for Exclusion & $\begin{array}{c}\text { Number of } \\
\text { Analyzed Articles }\end{array}$ \\
\hline \multirow{3}{*}{ Alliance projects } & ASCE & 10 & 1 & \multirow{3}{*}{$\begin{array}{l}\text { Irrelevant to alliance } \\
\text { delivery model in the } \\
\text { construction context }\end{array}$} & 9 \\
\hline & Emerald & 14 & 1 & & 13 \\
\hline & ScienceDirect & 19 & 13 & & 6 \\
\hline \multirow{3}{*}{$\begin{array}{c}\text { Integrated project } \\
\text { delivery }\end{array}$} & ASCE & 32 & 8 & \multirow{3}{*}{$\begin{array}{l}\text { Irrelevant to } \\
\text { integrated project } \\
\text { delivery in the } \\
\text { construction context }\end{array}$} & 24 \\
\hline & Emerald & 7 & 1 & & 6 \\
\hline & ScienceDirect & 16 & 1 & & 15 \\
\hline \multirow{3}{*}{ Partnering projects } & ASCE & 33 & 2 & \multirow{3}{*}{$\begin{array}{l}\text { Irrelevant to } \\
\text { partnering delivery } \\
\text { model in the } \\
\text { construction context }\end{array}$} & 31 \\
\hline & Emerald & 20 & 4 & & 16 \\
\hline & ScienceDirect & 42 & 26 & & 16 \\
\hline \multirow{3}{*}{$\begin{array}{l}\text { Relational } \\
\text { contracting }\end{array}$} & ASCE & 28 & 8 & \multirow{3}{*}{$\begin{array}{l}\text { Irrelevant to relational } \\
\text { contracting in the } \\
\text { construction context }\end{array}$} & 20 \\
\hline & Emerald & 13 & 8 & & 5 \\
\hline & ScienceDirect & 36 & 32 & & 4 \\
\hline \multirow{4}{*}{$\begin{array}{l}\text { Relationship- } \\
\text { based } \\
\text { procurement }\end{array}$} & ASCE & 0 & 0 & \multirow{4}{*}{$\begin{array}{l}\text { Irrelevant to } \\
\text { relationship-based } \\
\text { procurement in the } \\
\text { construction context }\end{array}$} & 0 \\
\hline & Emerald & 0 & 0 & & 0 \\
\hline & ScienceDirect & 1 & 1 & & 0 \\
\hline & Google Scholar & 10 & 1 & & 9 \\
\hline \multirow{4}{*}{$\begin{array}{l}\text { Lean project } \\
\text { delivery }\end{array}$} & ASCE & 2 & 0 & \multirow{4}{*}{$\begin{array}{l}\text { Irrelevant to lean } \\
\text { project delivery in the } \\
\text { construction context }\end{array}$} & 2 \\
\hline & Emerald & 2 & 1 & & 1 \\
\hline & ScienceDirect & 1 & 0 & & 1 \\
\hline & Google Scholar & 32 & 9 & & 23 \\
\hline \multicolumn{2}{|c|}{ Total } & 318 & 117 & - & 201 \\
\hline
\end{tabular}






Figure 2. Publication period of the analyzed studies.

\subsection{Conceptualization: Thematic Analysis and Model Development}

After locating the relevant studies, they were analyzed through thematic analysis [146]. This was undertaken by inductively coding the extracted research data as a result of reviewing the relevant studies. The labels of the codes were data derived by the researcher. According to the purpose of this study, the codes representing behavioral elements of collaborative delivery models were structured under a theme entitled "behavioral elements." Then, the codes under the developed theme (behavioral elements) were further analyzed for three main purposes: first, to identify and develop a list of the behavioral elements of collaborative delivery models; second, to detect the enablers contributing to the establishment of the behavioral elements; and third, to discover the interrelationships between the behavioral elements (i.e., how they influence each other). Finally, a pyramid model was developed based on the results of the conducted analysis.

\section{Results}

\subsection{Behavioral Elements of Collaborative Delivery Models}

As the first group of findings, Figure 3 presents the behavioral elements of the collaborative delivery models, which have been frequently mentioned in the literature. As can be seen in Figure 3, cooperation, collaboration, mutual trust, and open communication are the top four ones in terms of the ranking. Then, commitment to common goals, equality and mutual respect, and team integration are the next ones in the ranking. In this study, cooperation is defined as exchanging information between the project team members for the good of the project. Similarly, but not the same, collaboration is defined as working together for the best of the project. Team integration, here, is defined as the combination of collaboration and cooperation between project team members, representing different parties. Equality is defined here as the fair share of organizational and contractual authority, responsibility, risk, and reward between the project parties and team members throughout the project.

\subsection{Pyramid Model for Collaborative Project Delivery}

A pyramid model was developed for collaborative project delivery through analyzing the interrelationships of the mentioned behavioral elements in Figure 3. In other words, these elements were analyzed in order to find their linkages with each other and also their enablers. Appendix A includes the details of the explained thematic analysis for developing the pyramid model. The Appendix, in the big picture, provides research evidence concerning the enablers and interplay of the mentioned behavioral elements. 
The developed model consists of three components: (i) the pyramid, presenting the behavioral elements of collaborative delivery models and their interrelationships; (ii) common enablers of the presented elements in the pyramid; and (iii) the specific enablers of the presented behavioral elements in the pyramid. This classification of the enablers into "specific" and "common" categories is based on the thematic analysis results (Appendix A), meaning that some enablers contribute towards all of the presented behavioral elements in Figure 4, whereas some of the enablers only contribute to one or two of the behavioral elements.

\begin{tabular}{|c|c|c|c|c|c|c|c|c|c|c|c|c|c|c|c|c|c|c|c|c|c|c|c|c|c|c|c|c|c|c|c|}
\hline $\begin{array}{l}\text { Element/ } \\
\text { Reference }\end{array}$ & 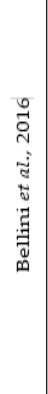 & 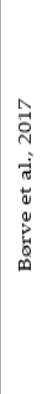 & 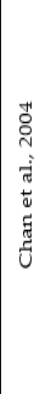 & 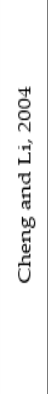 & 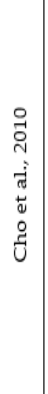 & 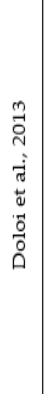 & 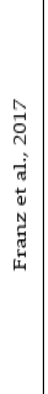 & 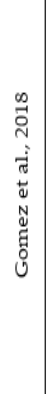 & 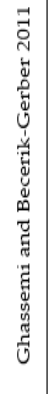 & 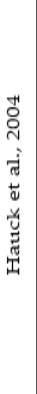 & 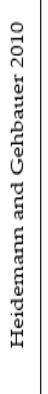 & 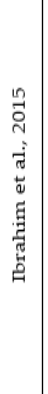 & 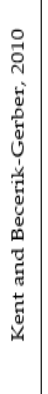 & 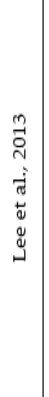 & 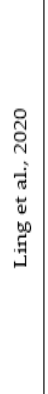 & 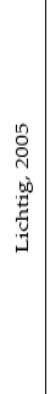 & 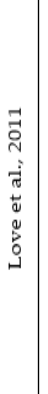 & 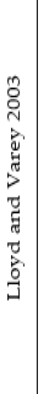 & 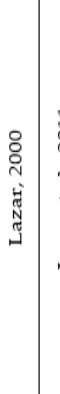 & 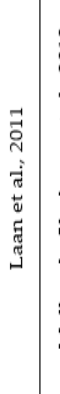 & 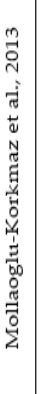 & 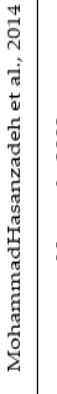 & 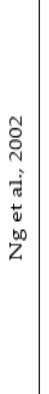 & 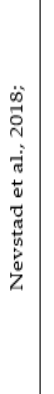 & 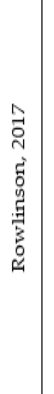 & 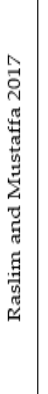 & 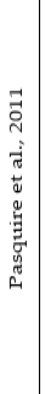 & 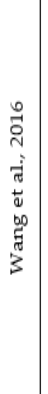 & 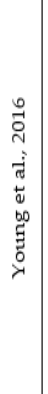 & 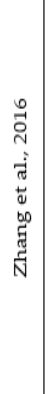 & 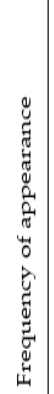 \\
\hline Cooperation & $\checkmark$ & $\checkmark$ & & & & $\checkmark$ & $\checkmark$ & & & $\checkmark$ & $\checkmark$ & $\checkmark$ & $\checkmark$ & $\checkmark$ & $\checkmark$ & $\checkmark$ & $\checkmark$ & & $\checkmark$ & & $\checkmark$ & & & $\checkmark$ & $\checkmark$ & & & & & $\checkmark$ & 17 \\
\hline Collaboration & $\checkmark$ & $\checkmark$ & & & & $\checkmark$ & $\checkmark$ & & & $\checkmark$ & $\checkmark$ & $\checkmark$ & $\checkmark$ & $\checkmark$ & $\checkmark$ & $\checkmark$ & $\checkmark$ & & $\checkmark$ & & $\checkmark$ & & & $\checkmark$ & $\checkmark$ & & & & & $\checkmark$ & 17 \\
\hline Mutual trust & $\checkmark$ & $\checkmark$ & & $\checkmark$ & & $\checkmark$ & & $\checkmark$ & $\checkmark$ & & & & $\checkmark$ & & & & & & $\checkmark$ & $\checkmark$ & & & & $\checkmark$ & $\checkmark$ & $\sqrt{ }$ & $\checkmark$ & $\checkmark$ & $\checkmark$ & $\checkmark$ & 17 \\
\hline $\begin{array}{c}\text { Open } \\
\text { communication }\end{array}$ & $\checkmark$ & & & $\checkmark$ & $\checkmark$ & $\checkmark$ & & & & & & & $\checkmark$ & & & & & $\checkmark$ & & & & & & $\checkmark$ & & $\checkmark$ & & $\checkmark$ & $\checkmark$ & & 10 \\
\hline $\begin{array}{l}\text { Commitment } \\
\text { to common } \\
\text { goals } \\
\text { (win-win } \\
\text { philosophy) }\end{array}$ & & & $\checkmark$ & $\checkmark$ & $\checkmark$ & & & & & & & & $\checkmark$ & & & & & & & & & $\checkmark$ & $\checkmark$ & & & $\checkmark$ & & $\checkmark$ & $\checkmark$ & & 9 \\
\hline $\begin{array}{c}\text { Equality \& } \\
\text { mutual respect }\end{array}$ & & & & & & & & $\checkmark$ & & & & & $\checkmark$ & & & $\checkmark$ & & & & & & & & & & & $\checkmark$ & $\checkmark$ & $\checkmark$ & & 6 \\
\hline $\begin{array}{l}\text { Team } \\
\text { integration }\end{array}$ & & & & & & & $\checkmark$ & & & & & $\checkmark$ & & $\checkmark$ & & $\checkmark$ & & & & & $\checkmark$ & & & & & & & & & & 5 \\
\hline
\end{tabular}

Figure 3. Behavioral elements of collaborative delivery models identified from the literature.



Figure 4. Pyramid model for collaborative project delivery. 
As can be seen in Figure 4, establishing the equality and mutual respect between project team members provides a basis for mutual trust and open communication. This is particularly important because the significance of equality has been considerably overlooked in previous studies as a critical enabler for trust development and open communication. As explained earlier, equality is the fair share of organizational and contractual authority, responsibility, risk, and reward between participants throughout the project. From this perspective, it can be argued that in a collaborative working environment with the win-win philosophy at its core, mutual trust, respect, and even constructive collaboration would only happen if the project team members see themselves as equal participants.

When equality and mutual respect are combined with mutual trust and open communication, the project team members have all prerequisites in place to work together (collaboration) and to exchange information (cooperation) for meeting common project objectives. Accordingly, team integration is achieved when equality and mutual respects fosters mutual trust and open communication, resulting in the collaboration and cooperation for the best of the project.

As can be seen in Figure 4, there are certain enablers which contribute to the creation of the aforementioned elements. A fair share of risk-reward, collaborative governance, commitment to common goals, and incremental as well as constructive interaction were found to be common contributors for the creation of equality and mutual respect, mutual trust and open communication, and for having collaborative cooperation. A building information model through which all team members can access, understand, and manage project information is another enabler which contribute toward equality and mutual respect, and mutual trust as well as open communication. Finally, an incentive payment structure was found to be of importance for facilitating collaboration and cooperation between project team members.

This developed model provides a new level of understanding regarding the interplay of behavioral elements of collaborative delivery models in construction projects. Although the mentioned behavioral elements of collaborative construction projects have been frequently mentioned in previous studies, such analytical and conceptual perspectives toward them are missing in the literature.

\section{Discussion}

The obtained results revealed the significance of establishing equality and mutual respect as the fundamental step toward trust development and open communication in collaborative project delivery. Moreover, it became evident that mutual trust and open communication are the prerequisites for constructive collaboration and cooperation, which eventually contribute to team integration. Furthermore, it was clarified that certain enablers contribute toward each of the mentioned behavioral elements. These findings seem to be in line with the previous research.

The findings of the studies conducted by $[99,147]$ imply that when equality and mutual respect exist between project team members, they are encouraged to trust each other and communicate openly. Another reason for this interrelationship would be this fact that the win-win philosophy, which is at the core of collaborative working environment, requires equality and mutual respect as the underlying step toward mutual trust and open communication. Moreover, previous studies have stated that team integration in collaborative construction projects requires project team members to collaborate and cooperate for the best of the project (e.g., [74,99]). Furthermore, it has been shown that project team members can work together and exchange information if they trust each other and there is an open line of communication (for instance, $[48,144]$ ).

In addition to the explained scientific logic behind the obtained results, one of the co-authors of this study with over 15 years of experience as an academic and executive expert of lean construction explained that "for example, the contract in alliance construction projects is very clear and each stakeholder is involved in the same contract with clear and agreed responsibilities and share of risk-reward. However, after the development phase, 
the design team plays a smaller role in the construction phase. Normally, the contactor starts to build and forgets the design team. In this case, the contractor's failure results in the design team's failure because equality and possibilities to influence end results in that case are small, and mutual trust and collaboration are weak throughout the project because of the missing equality. On the other hand, when the contractor and design team's mindset see equality and mutual respect as the fundamental constructs, it facilitates the establishment and continuation of mutual trust, open communication, and consequently, collaboration throughout the project, which eventually results in team integration," as it has been identified in this study.

In terms of the identified enablers, it has been stated in the previous studies that joint governance, fair share of risk-reward, commitment to common goals and incremental interaction are useful and effective for establishing equality, mutual respect, mutual trust and collaboration as well as cooperation (e.g., [47,63,76,79,148-152]). Moreover, Rowlinson, [81] asserted that equality, mutual trust, and collaboration are contributed through a building information model that all project participants can access, easily understand, and are also able to manage. In addition, the studies carried out by Hauck et al. [7] and Love et al. [62] revealed that a constructive incentive system is of prime importance for the collaboration and cooperation of project team members. According to the earlier explanations and this study's findings, pure team integration happens when the project team has already achieved equality, mutual trust, and collaboration as well as cooperation (e.g., [74,75]).

Regarding the enablers, it is also worth discussing the possible methods and technologies for their implementation. Among the identified enablers, collaborative governance, fair share of risk-reward, and an incentive payments system can be implemented throughout the project by incorporating these features into the contract in which project parties join. Realizing incremental and constructive interaction between project team members can be accomplished through on site (e.g., the co-location of the project team members) and/or virtual solutions (e.g., platforms such as Teams or Mural). The other identified enabler was a building information model (BIM) through which all team members can access, understand, and manage project information. This is necessary to highlight here that this enabler basically refers to the essence of the existence of BIM as a contributor to the establishment of equality, trust, and open communication, regardless of the challenges and complexities of employing and managing the BIM itself. The building information model data can be collected, updated, shared, and processed in various ways according to the building information modeling process and various BIM tools. Therefore, an in-depth study of the factors behind the success of the BIM as an enabler for equality, trust, and open communication is a potential area for future research.

These findings contribute to the existing body of knowledge and beyond by presenting a novel model which has explanatory capacity for portraying the interrelationships between the behavioral elements of collaborative delivery models in construction projects. The developed model can also be insightful for the research community and project professionals interested in trust development and team integration in temporary organizations.

In terms of practical implications, the study's findings can be insightful and valueadding for project professionals. First, the developed model (Figure 4) can be employed for facilitating the trust development between project participants and team integration when a collaborative construction project is launched. Second, it can also be utilized as a tool for monitoring, measuring, and enhancing the integration performance of the existing project delivery teams by utilizing the presented enablers in the model as the indicators of equality, trust and open communication, collaboration and cooperation, and team integration.

\section{Conclusions and Recommendations for Future Studies}

This study addressed the interrelationships of behavioral elements in collaborative project delivery and their enablers through developing a pyramid model for collaborative project delivery. The obtained results provided the basis for the following conclusions concerning the collaborative delivery models for construction projects: 
- Establishing the equality and mutual respect between project team members is the fundamental step toward trust development and open communication.

- Equality is the fair share of organizational and contractual authority, responsibility, risk, and reward between project parties and team members throughout the project.

- Equality and mutual respect together with mutual trust and open communication seem to be the prerequisites for constructive collaboration and cooperation between project team members.

- Achieving team integration requires collaboration (working together) and cooperation (exchanging information) between project participants for the best of the project.

These findings contribute to the body of knowledge on collaborative delivery models for construction projects through providing academic and practical insights for establishing integrated teams for productive construction project delivery. The generalizability of the findings of this study may even be beyond the construction projects and the developed model can be adapted for project delivery in other industries as well. As the limitations of this study, it is acknowledged that certain keywords were employed and searched in certain databases for locating the relevant studies, which narrowed its scope and might have affected its reliability and validity. Moreover, the developed model in this study needs to be tested in future studies and real projects in different contexts before it can be considered as generally accepted. Therefore, further studies in various regions and business conditions are a potential area for further research. In this regard, the following recommendations, which are based on the obtained results, can be the starting points for the future studies:

- $\quad$ Testing the developed model (Figure 4) in construction projects with alliance, partnering, IPD, and lean project delivery models through undertaking a survey among the practitioners of those projects.

- Exploring any discrepancy in terms of the effectiveness of the developed model (Figure 4) for the addressed collaborative delivery models in this study.

- Exploring contextual enablers for the presented behavioral elements in the model (Figure 4).

- An in-depth study of the factors behind the success of the building information modelling (BIM) as an enabler for equality, trust, and open communication.

Author Contributions: Conceptualization, S.M.; methodology, S.M.; formal analysis, S.M.; curation, S.M.; writing-original draft preparation, S.M.; writing-review and editing, S.M., K.K. and P.S.; supervision, K.K. and P.S. All authors have read and agreed to the published version of the manuscript.

Funding: This research received no external funding.

Institutional Review Board Statement: Not applicable.

Informed Consent Statement: Not applicable.

Data Availability Statement: Not applicable.

Conflicts of Interest: The authors declare no conflict of interest. 


\section{Appendix A. Interrelationships between Behavioral Elements of Collaborative Delivery Models}

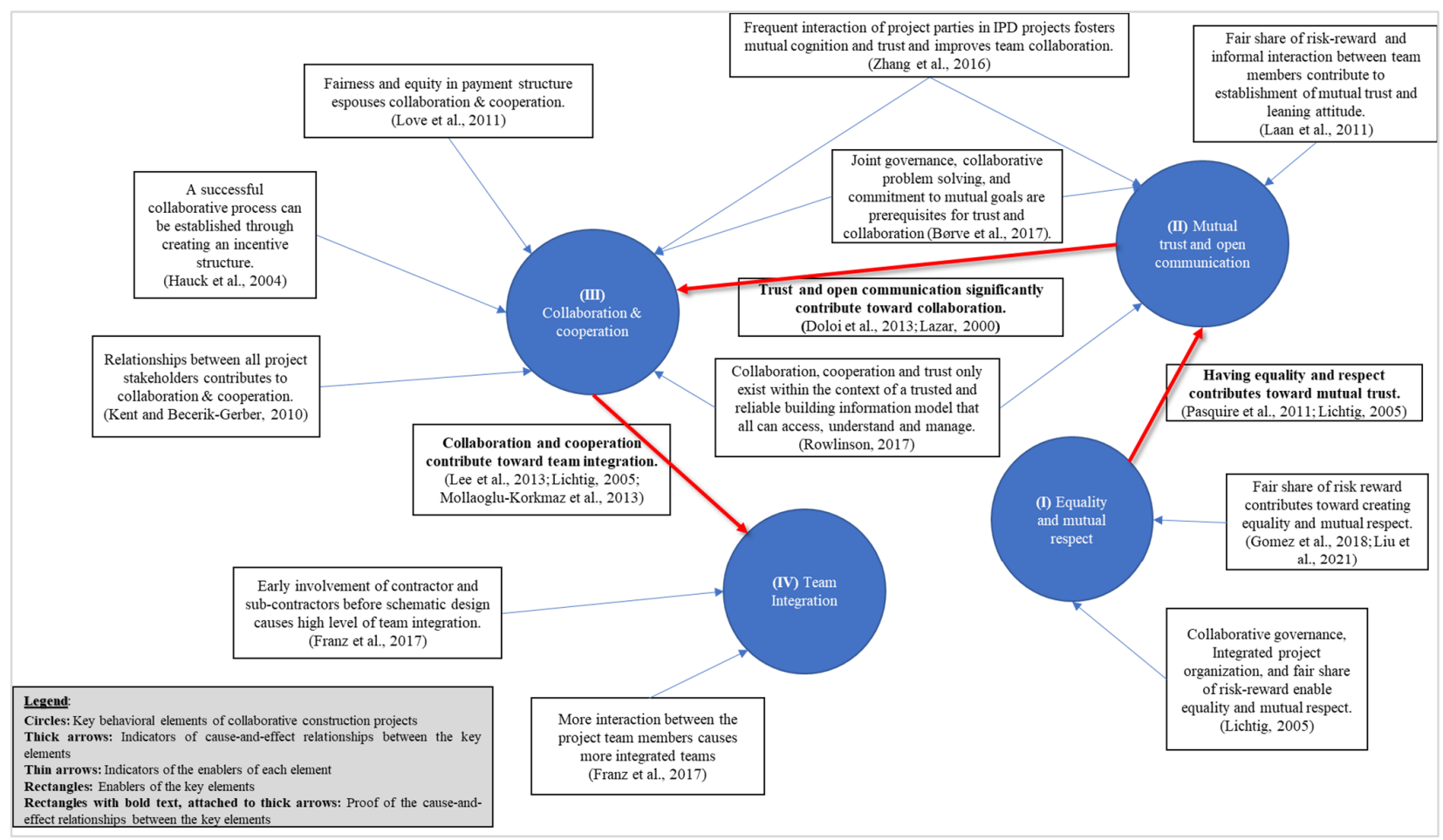

\section{References}

1. Mostafavi, A.; Karamouz, M. Selecting appropriate project delivery system: Fuzzy approach with risk analysis. J. Constr. Eng. Manag. 2020, 136, 923-930. [CrossRef]

2. Alarcón, L.F.; Mesa, H.; Howell, G. Characterization of lean Project delivery. In Proceedings of the 21st Annual Conference of the International Group for Lean Construction, Fortaleza, Brazil, 29 July-2 August 2013.

3. Chen, Y.Q.; Liu, J.Y.; Li, B.; Lin, B. Project delivery system selection of construction projects in China. Expert Syst. Appl. 2011, 38, 5456-5462. [CrossRef]

4. (CSI) Construction Specifications Institute. The CSI Project Delivery Practice Guide; John Wiley \& Sons: Hoboken, NJ, USA, 2011.

5. Kenig, M.E. An introduction. In Project Delivery Systems for Construction, 3rd ed.; The Associated General Contractors of America: Arlington, VA, USA, 2011; pp. 1-20.

6. Love, P.E.; Mistry, D.; Davis, P.R. Price competitive alliance projects: Identification of success factors for public clients. J. Constr. Eng. Manag. 2010, 136, 947-956. [CrossRef]

7. Hauck, A.J.; Walker, D.H.; Hampson, K.D.; Peters, R.J. Project alliancing at national museum of Australia-Collaborative process. J. Constr. Eng. Manag. 2004, 130, 143-152. [CrossRef]

8. Ibrahim, C.K.I.C.; Costello, S.B.; Wilkinson, S. Application of a team integration performance index in road infrastructure alliance projects. Benchmarking Int. J. 2016, 23, 1341-1362. [CrossRef]

9. Matthews, O.; Howell, G.A. Integrated project delivery an example of relational contracting. Lean Constr. J. 2005, 2, 46-61.

10. Ratajczak, J.; Schimanski, C.P.; Marcher, C.; Riedl, M.; Matt, D.T. Collaborative tool for the construction site to enhance lean project delivery. In International Conference on Cooperative Design, Visualization and Engineering; Springer: Cham, Switzerland, 2018; pp. 192-199.

11. Moradi, S.; Kähkönen, K.; Aaltonen, K. Project Managers' Competencies in Collaborative Construction Projects. Buildings 2020, 10, 50. [CrossRef]

12. Oakland, J.S.; Marosszeky, M. Total Construction Management: Lean Quality in Construction Project Delivery; Routledge: Abingdon, UK, 2017.

13. Fischer, M.; Khanzode, A.; Ashcraft, H.W.; Reed, D. Integrating Project Delivery; John Wiley \& Sons: Hoboken, NJ, USA, 2017.

14. Hosseini, A.; Haddadi, A.; Andersen, B.; Olsson, N.; Lædre, O. Relational base contracts-Needs and trends in Northern Europe. Procedia Comput. Sci. 2017, 121, 1088-1095. [CrossRef]

15. Moradi, S. Project Managers' Competencies in Collaborative Construction Projects. Ph.D. Thesis, Tampere University, Tampere, Finland, 2021. Available online: http:/ / urn.fi/URN:ISBN:978-952-03-2002-7 (accessed on 10 January 2022). 
16. Kumaraswamy, M.M.; Rahman, M.M.; Ling, F.Y.; Phng, S.T. Reconstructing cultures for relational contracting. J. Constr. Eng. Manag. 2005, 131, 1065-1075. [CrossRef]

17. Moradi, S.; Kähkönen, K.; Klakegg, O.J.; Aaltonen, K. A Competency Model for the Selection and Performance Improvement of Project Managers in Collaborative Construction Projects: Behavioral Studies in Norway and Finland. Buildings 2021, 11, 4. [CrossRef]

18. El Asmar, M.; Hanna, A.S.; Loh, W.Y. Evaluating integrated project delivery using the project quarterback rating. J. Constr. Eng. Manag. 2016, 142, 04015046. [CrossRef]

19. De Marco, A.; Karzouna, A. Assessing the benefits of the Integrated Project Delivery Method: A survey of Expert opinions. Procedia Comput. Sci. 2018, 138, 823-828. [CrossRef]

20. Forbes, L.H.; Ahmed, S.M. Modern Construction: Lean Project Delivery and Integrated Practices; CRC Press: Boca Raton, FL, USA, 2010.

21. Grajek, K.M.; Gibson, G.E.; Tucker, R.L. Partnered project performance in Texas Department of Transportation. J. Infrastruct. Syst. 2000, 6, 73-79. [CrossRef]

22. Hanna, A.S. Benchmark performance metrics for integrated project delivery. J. Constr. Eng. Manag. 2016, 142, 04016040. [CrossRef]

23. Hwang, B.G.; Ngo, J.; Her, P.W.Y. Integrated Digital Delivery: Implementation status and project performance in the Singapore construction industry. J. Clean. Prod. 2020, 262, 121396. [CrossRef]

24. Ibrahim, M.W.; Hanna, A.; Kievet, D. Quantitative comparison of project performance between project delivery systems. J. Manag. Eng. 2020, 36, 04020082. [CrossRef]

25. Wang, T.; Tang, W.; Du, L.; Duffield, C.F.; Wei, Y. Relationships among risk management, partnering, and contractor capability in international EPC project delivery. J. Manag. Eng. 2016, 32, 04016017. [CrossRef]

26. Hosseini, A.; Wondimu, P.A.; Bellini, A.; Haugseth, N.; Andersen, B.; Lædre, O. Project partnering in Norwegian construction industry. Energy Procedia 2016, 96, 241-252. [CrossRef]

27. Ballard, G. Rethinking project definition in terms of target costing. In Proceedings of the 14th Annual Conference of the International Group for Lean Construction, Santiago, Chile, 25-27 July 2006.

28. El-adaway, I.; Abotaleb, I.; Eteifa, S. Framework for multiparty relational contracting. J. Leg. Aff. Disput. Resolut. Eng. Constr. 2017, 9, 04517018. [CrossRef]

29. Harper, C.M.; Molenaar, K.R. Association between construction contracts and relational contract theory. In Construction Research Congress 2014: Construction in a Global Network; American Society of Civil Engineers (ASCE): Reston, VA, USA, 2014; pp. 1329-1338.

30. Han, J.; Rapoport, A.; Fong, P.S. Incentive structures in multi-partner project teams. Eng. Constr. Archit. Manag. 2019, 27, 49-65. [CrossRef]

31. Jagtap, M.; Kamble, S. An empirical assessment of relational contracting model for supply chain of construction projects. Int. J. Manag. Proj. Bus. 2019, 13, 1537-1560. [CrossRef]

32. Jones, B. Integrated project delivery (IPD) for maximizing design and construction considerations regarding sustainability. Procedia Eng. 2014, 95, 528-538. [CrossRef]

33. Kayis, B.; Zhou, M.; Savci, S.; Khoo, Y.B.; Ahmed, A.; Kusumo, R.; Rispler, A. IRMAS-development of a risk management tool for collaborative multi-site, multi-partner new product development projects. J. Manuf. Technol. Manag. 2007, 18, 387-414. [CrossRef]

34. Kadefors, A.; Björlingson, E.; Karlsson, A. Procuring service innovations: Contractor selection for partnering projects. Int. J. Proj. Manag. 2007, 25, 375-385. [CrossRef]

35. Mulholland, S.; Clevenger, C. Contracting Methods for Integrated Project Delivery: A Healthcare Case Study. In Construction Research Congress; American Society of Civil Engineers (ASCE): Reston, VA, USA, 2018; pp. 191-201.

36. Matinheikki, J.; Aaltonen, K.; Walker, D. Politics, public servants, and profits: Institutional complexity and temporary hybridization in a public infrastructure alliance project. Int. J. Proj. Manag. 2019, 37, 298-317. [CrossRef]

37. Matthews, J.; Tyler, A.; Thorpe, A. Pre-construction project partnering: Developing the process. Eng. Constr. Archit. Manag. 1996, 3, 117-131. [CrossRef]

38. Mastroianni, R.; Abdelhamid, T. The challenge: The impetus for change to lean project delivery. In Proceedings of the IGLC-11, 11th Conference of the International Group for Lean Construction, Blacksburg, VA, USA, 25-31 July 2003 ; pp. 418-426.

39. Mihic, M.; Sertic, J.; Zavrski, I. Integrated project delivery as integration between solution development and solution implementation. Procedia-Soc. Behav. Sci. 2014, 119, 557-565. [CrossRef]

40. Sarkar, D.; Mangrola, M. Development of lean integrated project delivery model for highway projects. Int. J. Constr. Proj. Manag. 2016, 8, 25

41. Piñero, J.C.; de la Garza, J.M. Issues related to the assessment of performance-based road maintenance contracts. In Towards a Vision for Information Technology in Civil Engineering; American Society of Civil Engineers: Reston, VA, USA, 2004; pp. 1-8.

42. Piroozfar, P.; Farr, E.R.; Zadeh, A.H.; Inacio, S.T.; Kilgallon, S.; Jin, R. Facilitating building information modelling (BIM) using integrated project delivery (IPD): A UK perspective. J. Build. Eng. 2019, 26, 100907. [CrossRef]

43. Sankaran, B.; Nevett, G.; O’Brien, W.J.; Goodrum, P.M.; Johnson, J. Civil Integrated Management: Empirical study of digital practices in highway project delivery and asset management. Autom. Constr. 2018, 87, 84-95. [CrossRef]

44. Wu, P.; Xu, Y.; Jin, R.; Lu, Q.; Madgwick, D.; Hancock, C.M. Perceptions towards risks involved in off-site construction in the integrated design \& construction project delivery. J. Clean. Prod. 2019, 213, 899-914. 
45. Yates, J.K.; Epstein, A. Avoiding and minimizing construction delay claim disputes in relational contracting. J. Prof. Issues Eng. Educ. Pract. 2006, 132, 168-179. [CrossRef]

46. Bellini, A.; Aarseth, W.; Hosseini, A. Effective knowledge transfer in successful partnering projects. Energy Procedia 2016, 96, 218-228. [CrossRef]

47. Børve, S.; Rolstadås, A.; Andersen, B.; Aarseth, W. Defining project partnering. Int. J. Manag. Proj. Bus. 2017, 10, 666-699. [CrossRef]

48. Doloi, H. Empirical analysis of traditional contracting and relationship agreements for procuring partners in construction projects J. Manag. Eng. 2013, 29, 224-235. [CrossRef]

49. Engebø, A.; Lædre, O.; Young, B.; Larssen, P.F.; Lohne, J.; Klakegg, O.J. Collaborative project delivery methods: A scoping review. J. Civil Eng. Manag. 2020, 26, 278-303. [CrossRef]

50. Lahdenperä, P. Making sense of the multi-party contractual arrangements of project partnering, project alliancing and integrated project delivery. Constr. Manag. Econ. 2012, 30, 57-79. [CrossRef]

51. Mesa, H.A.; Molenaar, K.R.; Alarcón, L.F. Comparative analysis between integrated project delivery and lean project delivery. Int. J. Proj. Manag. 2019, 37, 395-409. [CrossRef]

52. Ballard, G.; Howell, G. Lean project management. Build. Res. Inf. 2003, 31, 119-133. [CrossRef]

53. Hietajärvi, A.M.; Aaltonen, K.; Haapasalo, H. Managing integration in infrastructure alliance projects: Dynamics of integration mechanisms. Int. J. Manag. Proj. Bus. 2017, 10, 5-31. [CrossRef]

54. Hobbs, B.; Andersen, B. Different alliance relationships for project design and execution. Int. J. Proj. Manag. 2001, 19, 465-469. [CrossRef]

55. Halman, J.I.; Braks, B.F.M. Project alliancing in the offshore industry. Int. J. Proj. Manag. 1999, 17, 71-76. [CrossRef]

56. Ibrahim, C.K.I.C.; Costello, S.B.; Wilkinson, S. Making sense of team integration practice through the "lived experience" of alliance project teams. Eng. Constr. Archit. Manag. 2018, 25, 598-622. [CrossRef]

57. Pargar, F.; Kujala, J.; Aaltonen, K.; Ruutu, S. Value creation dynamics in a project alliance. Int. J. Proj. Manag. 2019, 37, 716-730. [CrossRef]

58. Lloyd, H.L.; Varey, R.J. Factors affecting internal communication in a strategic alliance project. Corp. Commun. Int. J. 2003, 8 197-207. [CrossRef]

59. Young, B.; Hosseini, A.; Lædre, O. The characteristics of Australian infrastructure alliance projects. Energy Procedia 2016, 96, 833-844. [CrossRef]

60. Ibrahim, C.K.I.C.; Costello, S.B.; Wilkinson, S. Establishment of quantitative measures for team integration assessment in alliance projects. J. Manag. Eng. 2015, 31, 04014075. [CrossRef]

61. Ibrahim, C.K.I.C.; Costello, S.B.; Wilkinson, S. Development of an assessment tool for team integration in alliance projects. Int. J. Manag. Proj. Bus. 2015, 8, 813-827. [CrossRef]

62. Love, P.E.; Davis, P.R.; Chevis, R.; Edwards, D.J. Risk/reward compensation model for civil engineering infrastructure alliance projects. J. Constr. Eng. Manag. 2011, 137, 127-136. [CrossRef]

63. Laan, A.; Voordijk, H.; Dewulf, G. Reducing opportunistic behaviour through a project alliance. Int. J. Manag. Proj. Bus. 2011, 4 , 660-679. [CrossRef]

64. Hietajärvi, A.M.; Aaltonen, K.; Haapasalo, H. Opportunity management in large projects: A case study of an infrastructure alliance project. Constr. Innov. 2017, 17, 340-362. [CrossRef]

65. Aaltonen, K.; Turkulainen, V. Creating relational capital through socialization in project alliances. Int. J. Oper. Prod. Manag. 2018, 38, 1387-1421. [CrossRef]

66. Hietajärvi, A.M.; Aaltonen, K.; Haapasalo, H. What is project alliance capability? Int. J. Manag. Proj. Bus. 2017, 10, 404-422. [CrossRef]

67. Baldwin, A.N.; Thorpe, A.; Carter, C. The use of electronic information exchange on construction alliance projects. Autom. Constr. 1999, 8, 651-662. [CrossRef]

68. Chen, G.; Zhang, G.; Xie, Y.M. Impact of transaction attributes on transaction costs in project alliances: Disaggregated analysis. J. Manag. Eng. 2015, 31, 04014054. [CrossRef]

69. Kok, R.A.; Creemers, P.A. Alliance governance and product innovation project decision making. Eur. J. Innov. Manag. 2008, 11, 472-487. [CrossRef]

70. Voordijk, H.; Plantinga, H.; Dorée, A. Procurement strategy formation:(re-) designing rail infrastructure project alliances. Int. J. Manag. Proj. Bus. 2016, 9, 53-73. [CrossRef]

71. Harper, D.G.; Bernold, L.E. Success of supplier alliances for capital projects. J. Constr. Eng. Manag. 2005, 131, 979-985. [CrossRef]

72. Sillars, D.N.; Kangari, R. Predicting organizational success within a project-based joint venture alliance. J. Constr. Eng. Manag. 2004, 130, 500-508. [CrossRef]

73. Kent, D.C.; Becerik-Gerber, B. Understanding construction industry experience and attitudes toward integrated project delivery. J. Constr. Eng. Manag. 2010, 136, 815-825. [CrossRef]

74. Lee, H.W.; Tommelein, I.D.; Ballard, G. Energy-related risk management in integrated project delivery. J. Constr. Eng. Manag. 2013, 139, A4013001. [CrossRef]

75. Franz, B.; Leicht, R.; Molenaar, K.; Messner, J. Impact of team integration and group cohesion on project delivery performance. J. Constr. Eng. Manag. 2017, 143, 04016088. [CrossRef] 
76. Zhang, L.; Cheng, J.; Fan, W. Party selection for integrated project delivery based on interorganizational transactive memory system. J. Constr. Eng. Manag. 2016, 142, 04015089. [CrossRef]

77. Mollaoglu-Korkmaz, S.; Swarup, L.; Riley, D. Delivering sustainable, high-performance buildings: Influence of project delivery methods on integration and project outcomes. J. Manag. Eng. 2013, 29, 71-78. [CrossRef]

78. Choi, J.; Yun, S.; Leite, F.; Mulva, S.P. Team integration and owner satisfaction: Comparing integrated project delivery with construction management at risk in health care projects. J. Manag. Eng. 2019, 35, 05018014. [CrossRef]

79. Gomez, S.; Naderpajouh, N.; Ballard, G.; Hastak, M.; Weidner, T.J.; Barriga, P. Implications of the Integrated Project Delivery Research in Practice. In Construction Research Congress; American Society of Civil Engineers (ASCE): Reston, VA, USA, 2018; pp. 86-96.

80. Hamzeh, F.; Rached, F.; Hraoui, Y.; Karam, A.J.; Malaeb, Z.; El Asmar, M.; Abbas, Y. Integrated project delivery as an enabler for collaboration: A Middle East perspective. Built Environ. Proj. Asset Manag. 2019, 9, 334-347. [CrossRef]

81. Rowlinson, S. Building information modelling, integrated project delivery and all that. Constr. Innov. 2017, 17, 45-49. [CrossRef]

82. Zhang, Y.; Hu, H. Utilization of a cognitive task analysis for integrated project delivery application: Case study of constructing a campus underground parking facility. Cogn. Syst. Res. 2018, 52, 579-590. [CrossRef]

83. Elghaish, F.; Abrishami, S.; Hosseini, M.R.; Abu-Samra, S.; Gaterell, M. Integrated project delivery with BIM: An automated EVM-based approach. Autom. Constr. 2019, 106, 102907. [CrossRef]

84. Liu, K.; Liu, Y.; Zhou, H.; Kou, Y.; Ji, Q.; Li, D. Evolutionary game and numerical simulation of participants' collaborative behavior in integrated project delivery project. Alex. Eng. J. 2021, 60, 373-385. [CrossRef]

85. Xie, H.; Liu, H. Studying contract provisions of shared responsibilities for integrated project delivery under national and international standard forms. J. Leg. Aff. Disput. Resolut. Eng. Constr. 2017, 9, 04517009. [CrossRef]

86. El-Adaway, I.H. Promoting the sustainability of relational contracting through addressing third party insurance obstacles. $J$. Manag. Eng. 2013, 29, 216-223. [CrossRef]

87. Ling, F.Y.; Teo, P.X.; Li, S.; Zhang, Z.; Ma, Q. Adoption of Integrated Project Delivery Practices for Superior Project Performance. J. Leg. Aff. Disput. Resolut. Eng. Constr. 2020, 12, 05020014. [CrossRef]

88. Whang, S.W.; Park, K.S.; Kim, S. Critical success factors for implementing integrated construction project delivery. Eng. Constr. Archit. Manag. 2019, 26, 2432-2446. [CrossRef]

89. Ballard, G. Lean Project Delivery System. White Pap. 2000, 8, 1-6.

90. Ballard, G. The Lean Project Delivery System: An Update. 2008. Available online: https://leanconstruction.org/uploads/wp/ media/library/id53/The_Lean_Project_Delivery_System_An_Update.pdf (accessed on 10 January 2022).

91. Nanda, U.; Rybkowski, Z.K.; Pati, S.; Nejati, A. A value analysis of lean processes in target value design and integrated project delivery: Stakeholder perception. Health Environ. Res. Des. J. 2017, 10, 99-115. [CrossRef]

92. Enache-Pommer, E.; Horman, M.J.; Messner, J.I.; Riley, D. A unified process approach to healthcare project delivery: Synergies between greening strategies, lean principles, and BIM. In Construction Research Congress: Innovation for Reshaping Construction Practice; American Society of Civil Engineers (ASCE): Reston, VA, USA, 2010; pp. 1376-1405.

93. Daniel, E.I.; Pasquire, C. Creating social value within the delivery of construction projects: The role of lean approach. Eng. Constr. Archit. Manag. 2019, 26, 1105-1128. [CrossRef]

94. Nguyen, P.; Akhavian, R. Synergistic effect of integrated project delivery, lean construction, and building information modeling on project performance measures: A quantitative and qualitative analysis. Adv. Civ. Eng. 2019, 2019, 1267048. [CrossRef]

95. Ahuja, R. Sustainable construction: Is lean green. In ICSDEC 2012: Developing the Frontier of Sustainable Design, Engineering, and Construction; American Society of Civil Engineers (ASCE): Reston, VA, USA, 2013; pp. 903-911.

96. Ghassemi, R.; Becerik-Gerber, B. Transitioning to Integrated Project Delivery: Potential Barriers and Lessons Learned. 2011. Available online: https://leanconstruction.org/uploads/wp/media/docs/ktll-add-read/Transitioning_to_Integrated_Project_ Delivery_Potential_barriers_and_lessons_learned.pdf (accessed on 10 January 2022).

97. Haarr, K.J.; Drevland, F. A mandated lean construction delivery system in a rehab project-A case study. In Proceedings of the 24th Annual Conference of the International Group for Lean Construction, Boston, MA, USA, 18-24 July 2016 ; Volume 1, pp. 3-12.

98. Darrington, J. Using a design-build contract for Lean Integrated Project Delivery. Lean Constr. J. 2011, $2011,85-91$.

99. Lichtig, W.A. Sutter health: Developing a contracting model to support lean project delivery. Lean Constr. J. 2005, 2, 105-112.

100. Nguyen, H.V.; Tommelein, I.D.; Ballard, G. Process-based cost modeling to support lean project delivery. In Proceedings of the 16th Annual Conference of the International Group for Lean Construction, Manchester, UK, 16-18 July 2008; pp. 577-588.

101. Klotz, L.E.; Horman, M.; Bodenschatz, M. A Lean Modeling Protocol for Evaluating Green Project Delivery. 2007. Available online: https:// tigerprints.clemson.edu/civileng_pubs/9/ (accessed on 10 January 2022).

102. Lapinski, A.R.; Horman, M.J.; Riley, D.R. Lean processes for sustainable project delivery. J. Constr. Eng. Manag. 2006, 132, 1083-1091. [CrossRef]

103. Macomber, H.; Howell, G. Linguistic action: Contributing to the theory of lean construction. In Proceedings of the 11th Annual Meeting of the International Group for Lean Construction, IGLC, Virginia, VA, USA, 22-24 July 2003; pp. 1-10.

104. Heidemann, A.; Gehbauer, F. Cooperative project delivery in an environment of strict design-bid-build tender regulations. In Proceedings of the 18th Annual Conference of the International Group for Lean Construction (IGLC-18), Perth, Australia, 28-31 July 2010; pp. 590-591. 
105. Anderson, L.L., Jr.; Polkinghorn, B.D. Efficacy of partnering on the Woodrow Wilson Bridge project: Empirical evidence of collaborative problem-solving benefits. J. Leg. Aff. Disput. Resolut. Eng. Constr. 2011, 3, 17-27. [CrossRef]

106. Bresnen, M.; Marshall, N. The engineering or evolution of co-operation? A tale of two partnering projects. Int. J. Proj. Manag. 2002, 20, 497-505. [CrossRef]

107. Bresnen, M. Deconstructing partnering in project-based organisation: Seven pillars, seven paradoxes and seven deadly sins. Int. J. Proj. Manag. 2007, 25, 365-374. [CrossRef]

108. Spang, K.; Riemann, S. Partnering in infrastructure projects in Germany. Procedia-Soc. Behav. Sci. 2014, 119, 219-228. [CrossRef]

109. Weston, D.C.; Gibson, G.E., Jr. Partnering-project performance in US Army Corps of Engineers. J. Manag. Eng. 1993, 9, 410-425. [CrossRef]

110. Walker, D.H.; Hampson, K.; Peters, R. Project alliancing vs project partnering: A case study of the Australian National Museum Project. Supply Chain. Manag. Int. J. 2002, 7, 83-91. [CrossRef]

111. McIntyre, M. (Ed.) Partnering: Changing Attitudes in Construction; AGC Publication No. 1225; The Associated General Contractors of America: Washington, DC, USA, 1995.

112. Nyström, J. The definition of partnering as a Wittgenstein family-resemblance concept. Constr. Manage. Econom. 2005, 235, 473-481. [CrossRef]

113. Thompson, P.J.; Sanders, S.R. Partnering continuum. J. Manag. Eng. 1998, 14, 73-78. [CrossRef]

114. Loraine, R.K. Project specific partnering. Eng. Constr. Archit. Manag. 1994, 1, 5-16. [CrossRef]

115. Brown, J. Partnering to save troubled projects. J. Manag. Eng. 1994, 10, 22-25. [CrossRef]

116. Gransberg, D.D.; Dillon, W.D.; Reynolds, L.; Boyd, J. Quantitative analysis of partnered project performance. J. Constr. Eng. Manag. 1999, 125, 161-166. [CrossRef]

117. Conley, M.A.; Gregory, R.A. Partnering on small construction projects. J. Constr. Eng. Manag. 1999, 125, 320-324. [CrossRef]

118. El-Adaway, I.H. Guidelines for a standard project partnering contract. In Construction Research Congress 2010: Innovation for Reshaping Construction Practice; American Society of Civil Engineers (ASCE): Reston, VA, USA, 2010; pp. 919-928.

119. El-Adaway, I.H. Integrated project delivery case study: Guidelines for drafting partnering contract. J. Leg. Aff. Disput. Resolut. Eng. Constr. 2010, 2, 248-254. [CrossRef]

120. Fortune, C.; Setiawan, S. Partnering practice and the delivery of construction projects for housing associations in the UK. Eng. Constr. Archit. Manag. 2005, 12, 181-193. [CrossRef]

121. Larson, E. Project partnering: Results of study of 280 construction projects. J. Manag. Eng. 1995, 11, 30-35. [CrossRef]

122. McFadden, E.M.; Ernzen, J.J. Partnered project performance at the city of Phoenix. In Construction Research Congress: Wind of Change: Integration and Innovation; American Society of Civil Engineers (ASCE): Reston, VA, USA, 2003; pp. 1-9.

123. Wang, T.; Tang, W.; Qi, D.; Shen, W.; Huang, M. Enhancing design management by partnering in delivery of international EPC projects: Evidence from Chinese construction companies. J. Constr. Eng. Manag. 2016, 142, 04015099. [CrossRef]

124. Yeung, J.F.; Chan, A.P.; Chan, D.W. A computerized model for measuring and benchmarking the partnering performance of construction projects. Autom. Constr. 2009, 18, 1099-1113. [CrossRef]

125. Yeung, J.F.; Chan, A.P.; Chan, D.W. Developing a performance index for relationship-based construction projects in Australia: Delphi study. J. Manag. Eng. 2009, 25, 59-68. [CrossRef]

126. Du, L.; Tang, W.; Liu, C.; Wang, S.; Wang, T.; Shen, W.; Zhou, Y. Enhancing engineer-procure-construct project performance by partnering in international markets: Perspective from Chinese construction companies. Int. J. Proj. Manag. 2016, 34, 30-43. [CrossRef]

127. Cheng, E.W. Intentions to form project partnering in Hong Kong: Application of the theory of planned behavior. J. Constr. Eng. Manag. 2016, 142, 04016075. [CrossRef]

128. Zhang, X.; Kumaraswamy, M.M. Procurement protocols for public-private partnered projects. J. Constr. Eng. Manag. 2001, 127, 351-358. [CrossRef]

129. Chan, A.P.; Chan, D.W.; Chiang, Y.H.; Tang, B.S.; Chan, E.H.; Ho, K.S. Exploring critical success factors for partnering in construction projects. J. Constr. Eng. Manag. 2004, 130, 188-198. [CrossRef]

130. Antonson, D.; Hoffman, B.; Yurovsky, T. Port Chicago Pipeline Project-A Partnering Success Story. In Building Partnerships; American Society of Civil Engineers (ASCE): Reston, VA, USA, 2000; pp. 1-5.

131. Cheng, E.W.; Li, H. Development of a practical model of partnering for construction projects. J. Constr. Eng. Manag. 2004, 130, 790-798. [CrossRef]

132. Cho, K.; Hyun, C.; Koo, K.; Hong, T. Partnering process model for public-sector fast-track design-build projects in Korea. J. Manag. Eng. 2010, 26, 19-29. [CrossRef]

133. Nevstad, K.; Børve, S.; Karlsen, A.T.; Aarseth, W. Understanding how to succeed with project partnering. Int. J. Manag. Proj. Bus. 2018, 11, 1044-1065. [CrossRef]

134. Ng, S.T.; Rose, T.M.; Mak, M.; Chen, S.E. Problematic issues associated with project partnering-The contractor perspective. Int. J. Proj. Manag. 2002, 20, 437-449. [CrossRef]

135. Crespin-Mazet, F.; Portier, P. The reluctance of construction purchasers towards project partnering. J. Purch. Supply Manag. 2010, 16, 230-238. [CrossRef]

136. Crespin-Mazet, F.; Havenvid, M.I.; Linné, Å. Antecedents of project partnering in the construction industry-The impact of relationship history. Ind. Mark. Manag. 2015, 50, 4-15. [CrossRef] 
137. Porwal, A.; Hewage, K.N. Building Information Modeling (BIM) partnering framework for public construction projects. Autom. Constr. 2013, 31, 204-214. [CrossRef]

138. Adnan, H.; Shamsuddin, S.M.; Supardi, A.; Ahmad, N. Conflict prevention in partnering projects. Procedia-Soc. Behav. Sci. 2012, 35, 772-781. [CrossRef]

139. Drexler, J.A., Jr.; Larson, E.W. Partnering: Why project owner-contractor relationships change. J. Constr. Eng. Manag. 2000, 126, 293-297. [CrossRef]

140. Radziszewska-Zielina, E.; Szewczyk, B. Supporting partnering relation management in the implementation of construction projects using AHP and fuzzy AHP methods. Procedia Eng. 2016, 161, 1096-1100. [CrossRef]

141. Sundquist, V.; Hulthén, K.; Gadde, L.E. From project partnering towards strategic supplier partnering. Eng. Constr. Archit. Manag. 2018, 25, 358-373. [CrossRef]

142. MohammadHasanzadeh, S.; Hosseinalipour, M.; Hafezi, M. Collaborative procurement in construction projects performance measures, case study: Partnering in Iranian construction industry. Procedia-Soc. Behav. Sci. 2014, 119, 811-818. [CrossRef]

143. Pena-Mora, F.; Harpoth, N. Effective partnering in innovative procured multicultural project. J. Manag. Eng. 2001, 17, 2-13. [CrossRef]

144. Lazar, F.D. Project partnering: Improving the likelihood of win/win outcomes. J. Manag. Eng. 2000, 16, 71-83. [CrossRef]

145. Laan, A.; Noorderhaven, N.; Voordijk, H.; Dewulf, G. Building trust in construction partnering projects: An exploratory case-study. J. Purch. Supply Manag. 2011, 17, 98-108. [CrossRef]

146. Saunders, M.N.K.; Lewis, P.; Thornhill, A. Research Methods for Business Students, 8th ed.; Pearson Education Limited: Harlow, UK, 2019.

147. Pasquire, C.; Ballard, G.; Darrington, J.W.; Howell, G.A. Motivation and incentives in relational contracts. J. Financ. Manag. Prop. Construction 2011, 16, 42-51. [CrossRef]

148. Raslim, F.M.; Mustaffa, N.E. The success factors of relationship-based procurement (RBP) in Malaysia. Int. J. Civ. Eng. Technol. 2017, 8, 1616-1625.

149. Swan, W.; Khalfan, M.M. Mutual objective setting for partnering projects in the public sector. Eng. Constr. Archit. Manag. 2007, 14, 119-130. [CrossRef]

150. Lloyd-Walker, B.; Walker, D. Collaborative Project Procurement Arrangements; Project Management Institute: Newtown Square, PA, USA, 2015.

151. Walker, D.; Hampson, K. Procurement Strategies: A Relationship-Based Approach; Blackwell Science: Oxford, UK, 2003.

152. Walker, D.H.T.; Jacobsson, M. A rational for alliancing within a public-private partnership: Engineering. Constr. Archit. Manag. 2014, 21, 648-673. [CrossRef] 